\title{
International Conference of Historians of the Labour Movement (ITH) at Linz, Austria
}

\author{
Irwin Wall \\ University of California, \\ Riverside
}

The twentieth conference of ITH met in Linz, Austria, from September 11-15, with close to 200 scholars in attendance. Two themes were taken up by the conference: "The Working-Class Movement and Colonialism between the Two World Wars," and "February 1934 in Austria and France." The nature of the themes brought an unprecedented number of participants from Africa, China, and Vietnam, in addition to those from Central and East Europe. Notable by their absence, however, were historians from Italy, Spain, and Latin America.

The unusually large turnout and presentation of papers meant that there was little time for speakers to develop their ideas from the floor. Confusion was also created by the failure of several participants, whose papers had been circulated, to appear, and by the intervention of speakers, whose printed texts either appeared only on the morning of the conference or not at all. The conference organizers often seemed more interested in getting to the conclusion of their daily agenda than in furthering discussion. But the conference was fruitful despite these limitations, permitting mutual understanding and the establishment of contacts between scholars who had not known of each others work. This participant, for example, was able to discuss mutual interests with scholars from Denmark, Holland, Germany, Poland, Hungary, Zaire, Nigeria, and Vietnam. The high point of the conference was a magisterial address by former Austrian Chancellor Bruno Kreisky, who brilliantly examined the current state of relations between developing and industrial nations in the light of the conference's major theme.

Needless to say one should not look for examples of the new social history, given the nature of conference themes. All the same, it is surprising that more historians present did not examine working class attitudes toward racism and imperialism rather than the resolutions and policies of specific parties and the internationals. A notable exception here was James Young's (Scotland) examination of the racism of British workers. The policies of the Communist International and its member parties tended to dominate the proceedings. The tendency of East Europeans, as exemplified by Hans Piazza (GDR), to justify virtually every Comintern policy, gloss over the famous "third period" with its doctrine of social fascism, and 
excuse "occasional mistakes" as the inevitable result of well-intended inexperience, was brilliantly criticized by Frances Klopćic of Yugoslavia, who raised what should have been the central theme of the conference: Is it legitimate any longer to assume that any specific social class in an imperialist nation inevitably had to oppose colonial oppression? Were there not subjective and perhaps objective conditions at work which prevented the identification of the proletariat with the colonized?

Perhaps the most interesting critique of the Comintern was offered by Wim Pelt of Holland, who noted a change in the line of the Chinese communists following the Ribbentrop-Molotov pact of August 1939 to an anti-Kuomintang position apparently disfavored by the Soviet Union. Strident criticism of Pelt by Ivan Lunjow (USSR) skirted the issue by insisting simplistically on the Soviet Union's principled support for the Chinese struggle against Japan. Zhang Peihang (CPR), while insisting on the autonomy of the Chinese party's line at the time, declined to comment on the specific issue of Soviet attitudes. Helmut Gruber's scathing attack on the Comintern's Negro policy in the U.S. produced a spirited challenge from Malcom Sylvers (Italy) and some of the conference's best dialogue. The latter was unfortunately marred by an ad hominem attack on Gruber by Josef Schleifstein (GFR). History blended into politics for a brief moment as some participants privately offered the view that behind the attack was the hand of Moscow.

The working-class movements in the colonial world were also examined. Worthy of note were Etienne Mbaya's (Zaire) tour de horizon of African working classes and Van Toa's (PRV) analysis of the Vietnamese working class. Despite implicit criticism of French communist policies toward Vietnam in his paper, and a spirited denunciation of the French communist's nationalism by Ernst Frey, an Austrian participant in the events of that era, Van Tao refused to respond to this writer's suggestion that the French communists after 1936 in fact became part of France's colonial consensus.

Most of the contributions concerning February 1934 in Austria stressed historiography, regional aspects of the events, or the repercussions in Poland, Czechoslovakia, and China. The contributions on the February events in France by János Jemnitz (Hungary) and Brian Jenkins (England) produced a spirited discussion of the Comintern shift of 1934, on which some new light was thrown by Felix Tych (Poland). The papers at Linz were uneven in quality, and the conference by its choice of themes and organization invited a high degree of politicization. All the same, one must repeat that fruitful exchanges did take place in amiable and congenial surroundings, helping to advance international understanding within the profession. It is hoped that American scholars will continue to participate. The conference provide simultaneous translation in English, French, and German, and its proceedings are published in an attractive format that deserves wider American distribution. 